(C) 2020 Katedra Białorutenistyki UW. Wydanie w otwartym dostępie na licencji CC BY-NC-ND (https://creativecommons.org/licenses/by-nc-nd/4.0/deed.pl).

ACTA ALBARUTHENICA 20: 2020

DOI: 10.32612/uw.18988091.2020.20.pp.199-208

Ірына Караткевіч /Iryna Karatkevich

Беларускі дзяржаўны ўніверсітэт / Belarusian State University

ORCID: https://orcid.org/0000-0002-8628-7318

e-mail: viachirynka@gmail.com

\title{
Слоўнік беларускай мовы Івана Насовіча: этналінгвістычны каментар
}

DICTIONARY OF THE BELARUSIAN LANGUAGE by Ivan Nosovich: ethnolinguistic comment SŁOWNIKJĘZYKA BIAŁORUSKIEGO Iwana Nosowicza: komentarz etnolingwistyczny

\section{1. Слоўнік беларускай мовы І. Насовіча ў беларускай лінгвістыцы}

Слоўнік беларускай мовы І. Насовіча (у арыгінале Словарь бълорусскаго нарпчія, Санкт-Пецярбург, 1870) у беларускай лінгвістычнай навуцы займае адметнае месца. Падрыхтоўка такога слоўніка была выклікана неабходнасцю навуковай сістэматызацыі выяўленай фальклорнай і канцылярска-справавой спадчыны беларускага народа старабеларускіх актаў, грамат, іншых пісьмовых помнікаў, фальклорных і этнаграфічных выданняў, многія з якіх паслужылі крыніцамі для рэестру слоўніка.

3'яўленне лексікаграфічнай працы, якая б пацвярджала культурна-этнаграфічную аўтэнтычнасць канкрэтнай этнічнай супольнасці ў межах Расійскай імперыі, было невыпадковым. Гістарычны кантэкст надзвычай спрыяў вывучэнню спецыфікі нацыянальных характараў, паколькі Расійская імперыя падтрымлівала працэс станаўлення нацыянальнай самасвядомасці паўднёвых, заходніх і ўсходніх славян, якія да гэтага знаходзіліся пад уладай адпаведна Асманскай і Аўстрыйскай імперый. Расійская імперыя

была таксама і адзінай суверэннай славянскай дзяржавай у свеце на працягу ўсяго XIX стагоддзя. Таму яна адыгрывала выключную ролю ў падтрымцы адраджэння іншых славянскіх народаў, у тым ліку ў распаўсюджанні ідэй панславізму (хаця часта расійскі ўрад меў на ўвазе свае вузкія інтарэсы ў адносінах да славянскіх народаў, што ўвайшлі ў склад Расійскай імперыі) [Савіцкая 2014: 207].

\section{У адносінах да сваіх заходніх тэрыторый}

расійскія ўлады актыўна разыгрывалі “беларускую карту”. <...> Ва ўрадавых статыстыках і картах выкарыстоўваецца тэрмін “беларусы” побач з назвамі "велікарусы” і “маларосы”, <..> улады дазволілі друкаваць на 
беларускай мове “грамадзянкай” этнаграфічныя зборнікі. Пашыралася ужыванне тэрміна Беларусь [Смалянчук 2020].

Таксама і Слоўнік беларускай мовы рыхтаваўся як другая частка Опыта словаря областных наречій Імператарскай Акадэміі навук (што выяўляла тагачаснае разуменне Акадэміяй навук беларускай мовы як дыялекту). Рэестр гэтай лексікаграфічнай крыніцы быў складзены на беларускай мове, а слоўнікавыя артыкулы перакладзены на рускую мову. Слоўнік нават удзельнічаў у конкурсе Акадэміі навук і быў адзначаны палавіннай Дзямідаўскай прэміяй. Фактычна, слоўнік I. Насовіча, як і многія іншыя даследаванні культуры і побыту беларусаў, быў пакліканы навукова падтрымаць афіцыйную ідэю заходнерусізму (Беларусь - этнаграфічная частка Расіі, яе нешматлікія культурныя і моўныя адрозненні - прыкры польскі ўплыў, падлеглы скасаванню). Аднак яго рэестравая і ілюстратыўная часткі толькі пацвердзілі існаванне самастойнага і этнаграфічна самабытнага беларускага этнасу.

Як адзначалася вышэй, паводле структуры і семантызацыі лексічных значэнняў рэестра слоўнік І. Насовіча варта лічыць тлумачальнаперакладным беларуска-рускім даведнікам: беларускія лексемы перакладаюцца рускамоўным адпаведнікам і суправаджаюцца граматычнымі пазнакамі, этымалагічным аналізам (у аўтарскім разуменні) і стылістычнай характарыстыкай. Адрозненне беларускай мовы

падкрэслівалася не толькі гістарычным і краязнаўчым каментаром, які надаў слоўніку пэўную гісторыка-культурную каштоўнасць, але і ўласна лінгвістычным аналізам многіх рэестравых адзінак, згодна з якім лексемы або праявіліся адрознымі ў параўнанні з іншымі мовамі, або набылі беларускую фанетычную ці граматычную спецыфіку пры запазычванні [Короткевич 2018].

3 мовазнаўчага погляду, слоўнік I. Насовіча варта разглядаць у якасці першага слоўніка беларускай літаратурнай мовы: ён выконваў функцыі вывучэння, апісання і нармалізацыі слоўнікавага складу мовы, а значыць, надаваў гэтай мове статус нацыянальнай. У ім назіраецца шэраг прымет, што характарызуюць яго як шматаспектную, высоканавуковую філалагічную працу: наяўнасць дэфініцый, тлумачэнне рэестравых беларускіх лексем з дапамогай сінанімічных пар і радоў, дакладна сфармуляваныя стылістычныя пазнакі. Праца І. Насовіча з'явілася першым вопытам колькасна і якасна значнай лексікаграфічнай апрацоўкі і навуковай сістэматызацыі лексіка-фразеалагічнага матэрыялу беларускай літаратурнай мовы. У XX стагоддзі слоўнік стаў “узорам, на які абапіраліся складальнікі лексікаграфічных прац 1920-х гг." [Караткевіч, Важнік, Уласевіч, Караткевіч 2018: 37]. Гэтыя факты дазваляюць сцвярджаць, што Слоўнік беларускай мовы І. Насовіча паклаў пачатак кадыфікацыі жывой беларускай гаворкі. Усё вышэйадзначанае вымагае адпаведнага аналізу рэестравага складу слоўніка І. Насовіча. У артыкуле рэестравая частка (словаспіс) будзе разглядацца ў аспекце 
адлюстравання ў ім этналінгвістычнага апісання беларускага насельніцтва і яго побыту.

\section{2. Этналінгвістыка як напрамак даследавання}

Для аналізу этналінгвістычнага складніка ў слоўніку I. Насовіча неабходна раскрыць сутнасць і межы гэтай навукі. Этналінгвістыка, паводле сучасных лінгвістычных падыходаў, гэта

адносна новы напрамак у мовазнаўстве, які вывучае мову ў яе адносінах да культуры, народа, а таксама ўзаемадзеянне этнакультурных і этнапсіхалагічных фактараў у функцыянаванні і эвалюцыі мовы [Дзядова 2019: 12].

Прасцей кажучы, гэта напрамак лінгвістыкі, які “інтэгруе ў сабе мовазнаўства, этнаграфію і фалькларыстыку" [Дзядова 2019: 12]. Адпаведна і аб'ектам этналінгвістыкі

з'яўляюцца ўсе бакі мовы як у яе вуснай форме (дыялекты, фальклор, прастамоўе, літаратурная мова), так і разнастайныя пісьмовыя тэксты (найперш арыгінальныя і перакладныя мастацкія творы). У якасці аб'екта вывучэння выступае не толькі мова, але і іншыя формы, у якіх выражае сябе калектыўная свядомасць, народны менталітэт, нацыянальная карціна свету, характэрная для таго ці іншага этнасу, - г. зн. уся народная духоўная культура, усе яе віды, жанры і формы - вербальныя (лексіка і фразеалогія, парэміялогія, фальклорныя тэксты), акцыянальныя (абрады), ментальныя (вераванні) [Дзядова 2019: 13].

Такім чынам, этналінгвістыка - гэта натуральны працяг дыялекталогіі, этымалогіі і гісторыі мовы, дзе лексіка і фразеалогія выступаюць крыніцай звестак пра гісторыю і культуру этнасу. Таму адметнае месца тут займаюць даследаванні анамастыкі, тапанімікі, запазычанняў, табу і эўфемізмаў - "усіх тых пластоў лексікону, што акумулююць фонавыя веды (традыцыі, факты культуры і гісторыі, народныя вераванні і каштоўнасці)" [Токарева 2001: 21].

Слоўнік I. Насовіча можна назваць падобным “акумулятарам" этналінгвістычных ведаў, паколькі ў яго рэестры і ілюстрацыйным матэрыяле выкарыстоўваюцца дыялектныя або агульналітаратурныя цытаты, аўтарскія тлумачэнні ў выглядзе ідыяматычных выразаў, прыказкі, прымаўкі, вытрымкі з фальклорных твораў, народных песень, загадак.

\section{3. Этналінгвістычны складнік Слоўніка беларускай мовы I. Насовіча}

Асноўныя задачы любога слоўніка звычайна раскрываюцца ў прадмовах. Прадмову да Слоўніка беларускай мовы I. Насовіча напісаў Канстанцін Весялоўскі, "Непремънный Секретарь Імператорской Академіи Наукъ". Прадмова займае толькі дзве старонкі, нават не мае нумарацыі старонак і не ўваходзіць у агульную нумарацыю ўсяго слоўніка, аднак мае адметную навуковую значнасць. Каштоўнасць прад- 
мовы заключаецца ў тым, што ў ёй пералічаны папярэднія лексікаграфічныя крыніцы, паказаная важнасць сістэматызацы беларускай гаворкі для далейшага выкарыстання ў мовазнаўстве (“для пониманія важныхъ и любопытныхъ историческихъ актовъ, на немъ писанныхъ"), арэал распаўсюджання "нарьчія", матэрыялы для рэестра.

Як ужо адзначалася, рэестравымі кампанентамі слоўніка паслужылі не толькі агульнаўжывальныя лексемы, але і лексічныя адзінкі, якія змяшчаюць у сабе этнаграфічную і культуралагічную характарыстыкі беларускага народнага побыту:

- н найменні міфічных істот, персанажаў з народных казак і забабонаў: баба-яга, бплунъ, вовколакъ, водяникъ, злыдзень, змпй, клетникъ, кляскунъ, ледащикъ:

Баба-Яга 1) Бранное слово на злую старуху. Чертовка или въдьма. 2) въ сказкахъ: Злой дух въ образђ старой отвратительной женщины. БЪлоруссы въ старину имъли повърье, будто баба-яга похищаетъ малыхъ дътей и питается ихъ мясомъ. И нынЊ малыхъ дътей стращаютъ бабойягой, чтобы они не плакали.

Баба-яга, косцяная нога

На ступь ьдзець,

Товкачомъ погоняець,

Помеломъ сльдъ замьтаець. (Сказка)

[Насовіч 1983: 10]

Змњй 1) Ужъ. Змъй укусивъ. Змъя забили. 2) ругат. Злой человъкъ. Змњю гетому ничимъ не догодзишъ, усё сипиць. 3) Метеоръ, пролетающій по небу огненною полосою, а иногда разсыпающійся искрами. Бълоруссы простолюдины и нынъ върятъ, что это злой духъ, который избранникамъ своимъ носитъ богатства. Если онъ пролетитъ полосою яркаго, огненнаго цвђта, значитъ, что несетъ золото, бльдноватою - серебро, а темноватою - хлъбъ въ зернъ. Иначе его называютъ смокомъ и цмокомъ (213);

- народных традыцый і рытуалаў: дъды, влазины, запоины, муровины, кумовины, радоница, толока:

Кумовины День посъщенія родильницы кумовьями и ихъ угощенія. Просили на кумовины (259);

Толока 1) Сельская полевая работа съ приглашенными на помощь сосьдями. Толокою вывозятъ навозъ, косятъ, жнутъ, пашутъ и проч.; угощеніе есть необходимое условіе толоки. Просивъ панъ на толоку, а не по́йдзешъ, и за лобъ поволоку. Посл. 2) собир. Прошенные на полевую работу сосъди.

Да гудзець поле, гудзець; толока съ поля идзець. Изъ ппсни.

Слава, да й слава, паночекъ, твоя:

Пьяна, да й пьяна, толока твоя. Изъ ппсни (636).

- страў нацыянальнай кухні: бигусъ, верещака, запеканка, зацирка, клёцки, крупникъ, кулешъ, ладка, прежпня:

1 Тут і далей прыклады даюцца гэтым па выданні з пазначэннем у дужках старонкі. 
Бигусъ кушанье изъ оставшагося отъ ужина жаркого, разкрошеннаго, притертого мукою и поджареннаго съ масломъ (25);

Крупникъ 1) Простой деревенскій супъ изъ крупъ; 2) Водка, сваренная съ медом, клюквою и пряными кореньями, въ родњ пунша (254-255);

- найменні ўдзельнікаў народных звычаяў і рытуалаў: бальшанка, волочобникъ, ворожбитъ, дружко, каравайница, купалка:

Бальшанка Дьвица, по приглашенію невьсты, безотлучно пребывающая съ нею до окончания свадьбы. Она вмъсть съ другою подобною шьетъ невЂсть приданое и особенно подвънечную одежу; во время же свадебнаго пиршенства или балю онъ объ сидятъ подль невъсты, какъ старшія подружки ея (14);

Дружко 1) Дружко, шаферъ. 2) Лицо, приглашенное женихомъ для увеселенія публики и распоряженія брачнымъ пиршествомъ.

Ульзъ дружко въ хату, да въ печь поглядаець,

Ци густа капуста, ци великъ горщокъ каши,

Ци пойдающь наши. Изъ свад. ппсни (146) і інш.

Этнаграфічныя і фальклорныя складнікі рэестра слоўніка дастаткова шматлікія:

а) памятники устной народной словесности: пњсни, пословицы, поговорки, сказки и др.; б) сборники словъ, собранные имъ [І. Насовічам I. К.] во время поњздокъ по Могилевской, Минской и Гродненской губерніямъ и по нЊкоторымъ окраинамъ губерній Привисленского края, смежнымъ съ вышеупомянутыми губерніями; в) алфавитный указатель старинныхъ Бълорусскихъ словъ, заключающихся въ актахъ Западной Россіи, который онъ составилъ по поручению Отдъленія [рускай мовы і славеснасці Імператарскай акадэміі навук (1865 г.) - I. К.]; г) Опытъ областнаго словаря Великорусскаго нарьчія, въ который вошло ньсколько небольшихъ сборниковъ словъ БЪлорусского наречія; д) матеріалы, впрочемъ не многочисленные, Бълорусского наречія и словесности, напечатанные въ Извъстіяхъ Императорской Академіи Наукъ по Отдъленію Русскаго языка и словесности, в Трудахъ Московскаго общества любителей словесности, въ Этнографическомъ сборникъ Императорскаго Русскаго географическаго общества, въ сборникахъ Чечета и Зенкевича [цыт.: Насовіч 1983: прадмова].

Этнаграфічныя кампаненты слоўніка выразна выяўляюцца не толькі ў відавочным пераліку матэрыялаў для рэестра, але і ў спісе скарачэнняў (адначасова і спіс стылістычных пазнак), што прыведзены складальнікам непасрэдна перад рэестрам. У гэтым спісе адсутны падзел на скарачэнні лінгвістычных тэрмінаў, этымалагічных і геаграфічных пазнак. Аднак у агульным пераліку вылучаюцца:

- абазначэнні геаграфічнага арэала распаўсюджання лексем: Брестский, Пинский, Пружанский уъздъ, Виленская, Гродненская, Минская, Могилевская губернія;

- этымалогія слоў, як яе разумеў сам І. Насовіч: Бълорусское, Греческое, древнее Славянское, Жидовское, Жидовско-Нпмецкое, Латинское, Литовское, от Польскаго (слова); 
- $\quad$ агульныя характарыстыкі паходжання слоў: дптское слово, заимствовано, извпстнаго значенія, областное (слово), отъ древняго слова, собственное отъ крещенія, старинное (слово), философическое (слово), церковное (слово), юридическое (слово);

- стылістычныя характарыстыкі слоў: бранное (слово), иронически, ласкательное (слово), негодованія (междометіе), ругательное (слово), смягчительное (слово), увеличительное (слово), укорительное (слово), уменьшительное (слово), уничижительное (слово);

- характарыстыкі фальклорных крыніц: волочебной (ппсни), духовной (ппсни), колыбельной (ппсни), крестинной (ппсни), поговорка, пословица, рекрутской (ппсни), свадебной (ппсни);

- характарыстыкі спецыфічнага ўжывання слоў: въ нравственномъ отношеніи, желательный, отъ мало употребительнаго, неупотребительнаго (слова), употребляемое въ среднемъ классп (народа) [Насовіч 1983: Объясненіе сокращенныхъ указаній въ Словарп].

Такая разгалінаваная сістэма аўтарскіх пазнак, падрабязная стылістычная дыферэнцыяцыя слоў, па-першае, сведчыць пра фарміраванне нацыянальнай беларускай лексікаграфічнай традыцыі; па-другое, паказвае сацыяльна-камунікатыўную разнастайнасць лексічных адзінак як адлюстраванне разнастайнасці побыту носьбітаў беларускай гаворкі.

\section{4. Запазычаная лексіка ў Слоўніку беларускай мовы І. Насовіча}

Указанне на паходжанне слова ў слоўніку даецца дастаткова паслядоўна. У прыватнасці, на польскамоўных запазычаннях у беларускай мове адмыслова засяроджана ўвага ў Прадмове да слоўніка:

Въ составъ словаря г. Носовича вошло болье 30000 словъ; между ними встрьчаются слова, заимствованныя изъ иностранныхъ языковъ, главнымъ же образомъ изъ Польскаго. Слова перешедшія изъ посльдняго языка преимущественно употребляются мелкою шляхтою, мБщанами, ремесленниками, экономами, прикащиками и пр. Количествомъ этихъ словъ и распространеніемъ употребленія ихъ въ народъ опредъляется нагляднымъ образомъ степень вліянія Польскаго языка на Бълорусское нарьчіе (цыт.: Насовіч 1983: прадмова).

Паланізмы ў рэестравым складзе Слоўніка беларускай мовы I. Насовіча афармляюцца праз прамое ўказанне на запазычанне з польскай мовы або ўказанне на існаванне ў польскамоўным побыце. Часам пры відавочным польскамоўным уплыве паходжанне слова не ўказваецца:

Альваръ Начальные основанія Латинскаго языка, составленныя іезуитомъ Альваресомъ, и бывшія въ употребленіи въ Польскихъ ксендзовскихъ училищахъ и даже въ православныхъ семинаріяхъ. (Слово ныне редко употребляемое.) Отъ Альвара просто до алтара. Посл. По альвару учився Лацины (5).

Войскій 1) Слово, оставшееся еще в употребленіи отъ Польскихъ чиновъ. Полковникъ. Панъ покойный Войскій Голынскій, хоць старъ бывъ, 
а ездивъ верхомъ хорошо. 2) Воинскій, военный. Вы войскіе людзи. Войская штука (63);

Вонтпливосць 1) Сомненіе. Пустая твоя вонтпливосць. 2) Пугливость. Заичча у цебе вонтпливосць. 3) Торопливость, неуместная поспешность. Черезъ вонтпливосць свою все дзъло спорцивъ (66);

Дэтоноваць 1) Сбівать съ толку, съ тону, перебивать. Не дэтонуй его, нехай пеець. 2) Приводить въ замешательство. Дэтонуешъ, здэтоновавъ на первомъ слове хлопца (150).

Зацненькій смягч. от Польск. Зацный. Хорошенькій, пригоженькій. Зацненькій хлопчикъ (192).

Продоляты Проволочка, откладываніе на будущее. Пусцивъ на продоляты то, што треба дзелаць скоро. Ты мене усё продолятами кормишъ, т. е. кормишъ завтраками (Заимств. изъ Польскаго) (522).

Аднак, акрамя лінгвістычнага запазычання, часта выяўляецца і сацыяльны "маркер" слова, г. зн. складальнік тлумачыць крыніцу з'яўлення слова ў побыце i, адпаведна, у маўленні носьбітаў мовы:

Авантура заимствованное простолюдинами изъ высшаго класса. 1) Удивительное происшествіе. Во якая авантура! 2) Шалость. Надзълавъ авантуры. 3) Бъда. Авантура съ тобою (2);

Дыета Діета. Слово употр. шляхтою и мњщанами. Съдзиць на дыець (149);

Линованне Графленіе, линеваніе. Линованне папери. (Слово употр. грамотными БЪлоруссами) (268);

Полирацыя 1) Образованіе (слово употр. среднимъ класомъ народа и въ особенности шляхтою, мъщанами и духовенствомъ). Ёнъ человък безъ полирацыи. 2) (между простолюдинами) Наказаніе. Давъ ему хорошую полирацыю, будзець помниць? (461);

Привата (употребляется горожанами). Посторонній доходъ, особенно за частные уроки. Привату маець опричь жалования. На привату ходзиць (497);

Припонтистое (употребляется грамотными, особенно духовными), перен. Заморское вино (от понтъ-море). Ромъ и всякое другое вино, прибавляемое къ чаю. А припонтистаго, съ припонтистымъ намъ не даси? (508);

Семпитэрня (отъ Лат. Sempiternus - всегдашній, заімствовано отъ школьниковъ). Задница, какъ бы всегдашняя, единственная отвътчица за проступки. Всыпали в семпитэрню (577).

Шматлікія запазычаныя словы пададзены з указаннем на іх паходжанне ў выглядзе стылістычнай пазнакі або ў якасці тлумачэння рэестравага слова. Аднак падрабязныя тлумачэнні складальніка пра нацыянальную прыналежнасць і ўмовы функцыянавання слова ўжо сведчаць пра шматэтнічную і шматканфесійную разнастайнасць насельніцтва Беларусі: 
Зелёные-святки 1) Праздникъ Сошествія Св. Духа (отъ украшенія храмовъ и домовъ зелеными вьтвями и отъ освященія въ день св. Троицы различныхъ, приносимыхъ въ храмъ травъ, которыя потомъ съ върою употребляются простолюдинами въ бользняхъ. Объ зеленыхъ святкахъ, зелеными святками приіъдзимъ. 2) Еврейскій праздникъ Пуримъ, бывающій чрезъ 50 дней посль Еврейскаго Пэйсаха или праздника Опрьсноковъ. Жидовскіе зелёные святки (207);

Кляшторъ Католическій монастырь. Бернардынскій кляшторъ (239);

Цымборія церк. Шкафъ или кивотъ съ дверцами, въ которомъ въ католическихъ и бывшихъ уніятскихъ церквахъ хранятся чаша и запасные дары; слово нынъ уже не употребляемое (692);

Читаная служба Литургія, отличавшаяся отъ спьваной и шептаной тьмъ, что уніатскіе священники совершали ее не на распьвъ и не съ пьніемъ клироса, но читая все то, что относится къ священническому служенію; при этомъ стоящій при священникъ прислужникъ читалъ все то, что долженъ былъ пьть клиросъ (699).

Прыведзеныя прыклады стылістычных пазнак і дэфініцый да рэестравых слоў апелююць да пэўных побытавых і духоўна-культурных рэалій, далёкіх ад пераважна сялянскага беларускага бытавання, паказваюць насычанасць і разнастайнасць жыцця розных пластоў насельніцтва беларускіх тэрыторый. Гэтыя ілюстрацыі разбураюць стэрэатыпныя ўяўленні пра "сялянскасць" беларускай мовы, яе побытава-зніжаны характар і немагчымасць перадачы абстрактных і высокастылёвых паняццяў.

Такім чынам, фальклорная аснова рэестра слоўніка I. Насовіча тлумачыцца імкненнем складальніка раскрыць этнічную аўтэнтычнасць беларускага насельніцтва. Зацікаўленасць складальніка нацыянальнай культурай, выкліканая спачатку тэндэнцыямі славянскага рамантызму, паглыбляецца адначасова з развіццём этнаграфіі і дыялекталогіi, што і абумоўлівае этналінгвістычны складнік слоўніка ў рэестравым, тлумачальным і ілюстратыўным апаратах працы. І. Насовіч паказвае фальклорнае паходжанне крыніц, размяшчае ў рэестры найменні міфічных персанажаў, удзельнікаў народных рытуалаў, элементаў побыту розных канфесій і сацыяльных пластоў, не проста семантызуючы іх, але і падаючы гісторыка-этнаграфічныя звесткі пра іх паходжанне. Усё гэта дало магчымасць паказаць лексіка-фразеалагічнае багацце беларускай мовы, сцвердзіць этнічную даўніну і культурную самабытнасць насельніцтва Беларусі і надаць слоўніку гісторыка-культурную каштоўнасць.

\section{Бібліяграфія}

Nasovič İ̀.̀̀. 1983. Sloǔnìk belaruskaj movy. Mìnsk: Belarus. Sav. Èncyklapedyâ [Насовіч I.I. 1983. Слоўнік беларускай мовы. Мінск: Беларус. Сав. Энцыклапедыя].

Dzâdova A.S. 2019. Ėtnalìngvistyka dlâ specyâl'nascì 1-21 0501 Belaruskaâ filalogiâ (pa napramkah). Vìcebsk: VDU ìmâ P.M. Mašèrava. [Дзядова А.C. 2019. Этна- 
лінгвістыка для спещыяльнасці 1-21 0501 Беларуская філалогія (па напрамках). Віцебск: ВДУ імя П.М. Машэрава].

Tokareva I.I. 2001. Ètnolingvistika i ètnografiâ obŝeniâ. Minsk: Minsk. gos. lingvist. un-t. [Токарева И.И. 2001. Этнолингвистика и этнография общения. Минск: Минск. гос. лингвист. ун-т].

Smalânčuk Ales'. Lìcvìnstva, zahodnerusizm ì belaruskaâ ìdèâ. XIX - pačatak XX st. [Смалянчук Алесь. Ліцвінства, заходнерусізм і беларуская ідэя. ХІХ - пачатак XX cm.] [online] http://kamunikat.org/7983.html [доступ: 30.05.2020].

Savìckaâ Ìryna. 2014. Gìstaryčny ì kul'turny skladnikì ǔ belaruskìm ì pol'skìm sloǔnikah nacyânal'naga značènnâ (na matèryâle sloǔnikaǔ S.B. Lìndè ì İ. Nasoviča). "Acta Albaruthenica” № 14: 205-216 [Савіцкая Ірына. 2014. Гістарычны і культурны складнікі у беларускім і польскім слоўніках нацыянальнага значэння (на матэрыяле слоўнікаў С.Б. Ліндэ і І. Насовіча). "Acta Albaruthenica" № $14: 205-216]$.

Korotkevič Irina. 2018. SLOVAR' BELARUSKOGO NAREČIÂ I.I. Nosoviča v kontekste slavânskogo romantizma [Короткевич Ирина. 2018. СЛОВАРЬ БЕЛАРУСКОГО НАРЕЧИЯ И.И. Носовича в контексте славянского романтизма] [online] http://abcdar. com/magazine/XI/Korotkevich_1_1314-9067_XI.pdf [доступ: 30.05.2020].

Karatkevič Ì.İ., Važnìk S.A., Ulasevìc V.İ., Karatkevič V.İ. 2018. Belaruskâ̂ leksika ì gramatyka: moǔnaâ styhîa ì moǔnaâ norma. Kìeǔ: Lìra-K. [Караткевіч I.I., Важнік С.А., Уласевіч B.I., Караткевіч B.I. 2018. Беларуская лексіка і граматыка: моўная стыхія і моўная норма. Кіеў: Ліра-К].

ABSTRACT: The Dictionary of the Belarusian Language by I.I. Nasovich (1870) is an important source of ethnolinguistic observations. In its register, it contains lexemes corresponding to the names of religious holidays and confessional realities, folk customs and rites. A significant layer of words has etymological information (not always accurate), including an indication of their foreign origin. The ethnolinguistic component consists not only of the selection of appropriate Belarusian and borrowed vocabulary, but also the design of stylistic labels for registry words that refer to certain everyday and spiritual-cultural realities, far from the predominantly peasant Belarusian life. These factors destroy the stereotypes about the "peasantry" of the Belarusian language, its reduced character and the impossibility of conveying abstract and high-style concepts.

KEYWORDS: ethnolinguistics, I.I. Nosovich, ethnography, folklore, loanwords.

STRESZCZENIE: Słownik języka białoruskiego I. Nasowicza (1870) jest ważnym źródłem do badań etnolingwistycznych. W swoim rejestrze zawiera leksemy-nazwy świąt religijnych i realiów wyznaniowych, zwyczajów i obrzędów ludowych. Znacząca warstwa słów zawiera informacje etymologiczne (nie zawsze dokładne), w tym również wskazanie na ich obce pochodzenie. Element etnolingwistyczny obejmuje nie tylko odpowiednie słownictwo białoruskie i zapożyczone, lecz także kwalifikatory stylistyczne do znajdujących się w rejestrze słów, które odnoszą się do zjawisk duchowych i kulturowych, dalekich od głównie chłopskiego życia na Białorusi. Wskazane czynniki burzą stereotypy o „chłopskim” pochodzeniu języka białoruskiego, za pomocą którego można informować jedynie o realiach życia codziennego, bez możliwości przekazywania pojęć abstrakcyjnych oraz cech wysokiego stylu.

SŁOWA KLUCZOWE: etnolingwistyka, I. Nosowicz, etnografia, folklor, zapożyczenia.

РЭЗЮМЭ: Слоўнік беларускай мовы I. Насовіча (1870 г.) з'яўляецца важнай крыніцай для этналінгвістычных назіранняў. У сваім словаспісе ён утрымлівае лексе- 
мы - назвы рэлігійных свят і канфесійных рэалій, народных звычаяў і абрадаў. Значны пласт слоў мае этымалагічныя звесткі (не заўсёды дакладныя), у тым ліку і ўказанне на іх іншамоўнае паходжанне. Этналінгвістычны складнік заключаецца не толькі ў падборы адпаведнай уласнабеларускай і іншамоўнай лексікі, але і ў афармленні стылістычных пазнак да рэестравых слоў, якія апелююць да пэўных побытавых і духоўна-культурных рэалій, далёкіх ад пераважна сялянскага беларускага жыцця. Названыя фактары разбураюць стэрэатыпныя ўяўленні пра “сялянскасць" беларускай мовы, яе побытава-зніжаны характар і немагчымасць перадачы абстрактных і высокастылёвых паняццяў.

КЛючАВЫЯ СловЫ: этналінгвістыка, І.Насовіч, этнаграфія, фальклор, запазычанні. 